\title{
GENETICAL STUDIES IN ACACIAS
}

\section{CHLOROSIS IN INTERSPECIFIC HYBRIDS}

\author{
A. A. MOFFETT \\ Wattle Research Institute, University of Natal
}

Received I0.iv.65

\section{INTRODUCTION}

IN the course of a tree breeding programme with Acacias a number of crosses were made between species of $\tan$ wattles with a view to producing hybrids of economic value. The hybrids obtained proved to be of little commercial use (Moffett and Nixon, 1958), but they showed complex behaviour in the occurrence of chlorotics and chimeras in their offspring. A study of the genetics of these hybrids was impeded by the high degree of sterility encountered, but the results to date are described here.

\section{MATERIAL}

The first recorded attempt to produce hybrids between species of tan wattles under controlled conditions was made in 1943 (Philp and Sherry, 1947) when inflorescences on two green wattle (Acacia decurrens) trees, numbered $\mathrm{G}_{33}$ and $\mathrm{G}_{35}$, were pollinated with black wattle (A. mearnsii, formerly A. mollissima). A number of hybrids were produced from these pollinations, but in the family from $\mathrm{G}_{33}$ only one (G33-24) survived to flowering stage. From $\mathrm{G}_{35}$, seven hybrids survived to flowering and five of these, $\mathrm{G}_{35-19}, \mathrm{G}_{35-21}, \mathrm{G}_{35-24}, \mathrm{G}_{35-25}$ and $\mathrm{G}_{35-30}$ were used by the writer for further breeding work. In $195 \mathrm{I}, F_{2}$ families were grown from both $\mathrm{G}_{33-24}$ and the five hybrids from $\mathrm{G}_{35}$. Families were also grown from $\mathrm{G}_{35-19}, \mathrm{G}_{35-2 \mathrm{I}}$, and $\mathrm{G}_{35-25}$ backcrossed to a black wattle tree $\mathrm{B}_{5}$ and from $\mathrm{G}_{35-21}$ to a green wattle tree $\mathrm{G}_{3}$. In making all these backcrosses the hybrids were used as seed parents, partly to take advantage of the dominant shorter period for seed ripening of green wattle and partly because it seemed likely that ovule sterility would be less than pollen sterility in the hybrids.

There was considerable variation between the $F_{1}$ hybrids, even from the same cross so it seemed probable that further crosses would yield even more widely varying hybrids. In 1950, reciprocal cross-pollinations were made between green and black wattles. The black wattle tree $\mathrm{B}_{5}$ was used to pollinate four green wattle trees $\mathrm{G}_{1}, \mathrm{G}_{2}, \mathrm{G}_{3}$ and $\mathrm{G}_{4}$ and it served as seed parent in crosses with the green wattles $\mathrm{G}_{2}$ and $\mathrm{G}_{5}$.

Interspecific hybridisation was confined mainly to crosses between green and black wattles and this paper is largely concerned with these hybrids. In 1950, inflorescences of the black wattle $\mathrm{B}_{5}$ were pollinated with $A$. baileyana and reciprocal crosses were made between $\mathrm{B}_{5}$ and silver wattle $(A$. dealbata) using two trees numbered $\mathrm{S}_{1}$ and $\mathrm{S}_{2}$. The silver wattle tree $\mathrm{S}_{2}$ was also pollinated with $\mathrm{G}_{5}$.

Crossing with different black wattle trees would have been desirable, but $\mathrm{B}_{5}$ had to be used extensively because of its time of flowering. Green and silver wattle, and $A$. baileyana all flower in July or August, whereas black wattle normally does not flower until September or October. $B_{5}$ was a tree derived from an air-layer and possibly because of this flowered early, so that there was a considerable overlap between its time of flowering and that of the other three species. 


\section{FERTILITY OF THE $F_{1}$ HYBRIDS}

It is not easy to devise a satisfactory method of measuring fertility in wattles since the inflorescence is a panicle of some hundreds of globose heads each consisting of $35-40$ closely packed minute flowers. An average sized inflorescence consists of well over 20,000 flowers and even with open-pollination, and under the most favourable conditions, only a small fraction of these flowers can form pods. The number of pods formed per inflorescence varies greatly from tree to tree and with the type of pollination, self-pollination usually producing

TABLE 1

Fertility of hybrids following different types of pollination

The number of inflorescences bagged is given in brackets.

\begin{tabular}{|c|c|c|c|c|c|c|c|c|c|c|c|}
\hline \multirow[b]{2}{*}{ Hybrids } & \multicolumn{3}{|c|}{ Selfed } & \multicolumn{3}{|c|}{$\times$ Black wattle } & \multicolumn{3}{|c|}{$\times$ Green wattle } & \multicolumn{2}{|c|}{$\begin{array}{c}\text { Open- } \\
\text { pollination }\end{array}$} \\
\hline & $\begin{array}{l}\text { No. } \\
\text { of } \\
\text { pods }\end{array}$ & $\begin{array}{c}\text { Mean } \\
\text { seeds } \\
\text { per } \\
\text { pod }\end{array}$ & $\begin{array}{c}\text { Fertility } \\
\text { per } \\
\text { cent. }\end{array}$ & $\begin{array}{l}\text { No. } \\
\text { of } \\
\text { pods }\end{array}$ & $\begin{array}{c}\text { Mean } \\
\text { seeds } \\
\text { per } \\
\text { pod }\end{array}$ & $\begin{array}{c}\text { Fertility } \\
\text { per } \\
\text { cent. }\end{array}$ & $\begin{array}{l}\text { No. } \\
\text { of } \\
\text { pods }\end{array}$ & $\begin{array}{l}\text { Mean } \\
\text { seeds } \\
\text { per } \\
\text { pod }\end{array}$ & $\begin{array}{c}\text { Fertility } \\
\text { per } \\
\text { cent. }\end{array}$ & $\begin{array}{c}\text { Mean } \\
\text { seeds } \\
\text { per } \\
\text { pod }\end{array}$ & $\begin{array}{l}\text { Fertility } \\
\text { per } \\
\text { cent. }\end{array}$ \\
\hline $\begin{array}{l}\text { Green } \times \\
\text { Black } \\
\quad(5 \text { trees })\end{array}$ & $\begin{array}{c}612 \\
(35)\end{array}$ & $0 \cdot 81$ & $5 \cdot 8$ & $\begin{array}{r}236 \\
(9)\end{array}$ & 4.05 & $28 \cdot 9$ & $\begin{array}{c}9^{6} \\
(12)\end{array}$ & $2 \cdot 00$ & $14 \cdot 3$ & $2 \cdot 84$ & $20 \cdot 2$ \\
\hline $\begin{array}{l}\text { Black } \times \\
\text { Green } \\
\text { ( } 7 \text { trees })\end{array}$ & $\begin{array}{l}360 \\
\left(3^{88)}\right.\end{array}$ & 0.21 & $1 \cdot 5$ & $\begin{array}{r}82 \\
\text { (10) }\end{array}$ & 0.28 & $2 \cdot 0$ & $\begin{array}{l}24 \\
(8)\end{array}$ & 0.08 & 0.6 & $2 \cdot 08$ & $14 \cdot 8$ \\
\hline
\end{tabular}

a much smaller number of pods per inflorescence than open-pollination. As it is not feasible to count the number of flowers, the number of pods set per inflorescence gives only a very rough estimate of fertility. A somewhat better measure is the number of seeds per pod and this was mainly used as a measure of fertility. Each flower has a potential of 14 seeds per pod and fertility can be expressed as a percentage of this potential (Moffett, 1956). Both green and black wattles produce on the average about seven seeds per pod on open-pollination and 2.5 seeds per pod on selfing, i.e. 50 and 18 per cent. fertility respectively. Both pod and seed production was lower in the hybrids than the parents (table $\mathrm{I}$ ).

This decreased fertility must be due, to a considerable extent, to zygotic elimination rather than to failure of fertilisation since a high proportion of embryos develop partially and subsequently degenerate at stages ranging from very tiny embryos to almost full-sized, but shrivelled, seeds.

When green wattle was the seed parent of the hybrid, fertility seemed to be higher than that of the reciprocal cross, both on selfing and backcrossing, but the comparison must be taken with reserve 
since the two sets of crosses were made in different years and there are indications that seasonal factors can play an important part in determining wattle fertility. The fertility of the green $\times$ black hybrid on backcrossing to black wattle was, however, much higher than on backcrossing to the green parent or with self or open-pollination.

Seed from open-pollination of the $F_{1}$ hybrids may have resulted from intercrossing between the hybrids or, owing to their position in the plantation, natural backcrossing to green wattle which was flowering freely close by. Because of the position and time of flowering, natural backcrossing to black wattle was unlikely.

\section{CHLOROSIS IN $F_{1}$ HYBRIDS}

Since emasculation before crossing is not practicable, the success of cross-pollination between species depends, to some extent upon the partial self-sterility of the female parent. Families from crosspollinations may, therefore, be a mixture of selfed seedlings and hybrids.

Philp and Sherry (1947) noted that in "crossed" families a number of chlorotic seedlings occurred as well as normal blue-green (BG) seedlings, the degree of chlorosis varying, between seedlings, from yellow-green ( $Y G$ ) to pale green $(G)$. No chlorotics were found in the small families from controlled self-pollination of the seed parents used for the cross-pollinations. Of 7 seedlings from $\mathrm{G}_{33}$ pollinated with black wattle, 5 were chlorotic and 2 normal. One of each type died at an early stage, but the remainder were all hybrids. In the family derived from pollinating $\mathrm{G}_{35}$ with black wattle, 9 seedlings survived to be classified; 7 were chlorotic and hybrid while two were normal, one being hybrid and the other a green wattle self.

The series of similar crosses made by the writer in $195^{\circ}$ resulted in 30 seedlings which could be classified. Twelve of these were BG and proved to be green wattle, one doubtful YG was also green wattle, while 17 YG seedlings were all hybrid.

The occurrence of chlorotic hybrid seedlings suggested that a cytoplasmic interaction might be involved and reciprocal crosses were made to determine whether hybrid chlorosis depended upon the direction of the cross. From the cross-pollinations with black wattle as seed parent 42 seedlings could be classified and of these 33 BG seedlings proved to be black wattle selfs and 9 YG seedlings were hybrids. Selfed families from the black wattle parent showed no segregation for YG.

The degree of chlorosis in $F_{1}$ hybrids between green and black wattles not only varies between seedlings, but changes rapidly with age, coming closer to the normal colour as the leaf matures. Because of this, scoring is sometimes difficult and it is possible that hybrid seedlings previously classified as being BG may have had a degree of chlorosis which was overlooked. However, the differences between 
the $\mathrm{F}_{2}$ family from $\mathrm{G}_{33-24}$, a hybrid scored as having normal seedling leaf colouring, and those from definitely chlorotic seedlings show that variation in the degree of chlorosis in $F_{1}$ hybrids has a genetical significance (see below).

It would seem that a degree of chlorosis in the $F_{1}$ seedling is a usual if not universal concomitant of hybridity in crosses between green and black wattles and that it occurs irrespective of the direction in which the cross is made.

Chlorosis also occurred following crosses involving other species. The black wattle $\mathrm{B}_{5}$ pollinated with $A$. baileyana yielded 12 seedlings which could be classified. Of these $6 \mathrm{BG}$ seedlings proved to be black wattle selfs and 6 YG seedlings were hybrid. The degree of chlorosis in these was very similar to that in the green-black hybrids. When $\mathrm{B}_{5}$ was pollinated with silver wattle $\left(A\right.$. dealbata) tree No. $\mathrm{S}_{1}, 29 \mathrm{BG}$ and 3 YG seedlings were produced. Twenty-eight of the BG seedlings were black selfs while one, a dwarf type, was a doubtful hybrid which died before it could be classified with certainty. All three YG seedlings were hybrids. When the second silver wattle tree $\mathrm{S}_{2}$ was pollinated with $\mathrm{B}_{5}$, seed was set fairly freely and of $5^{\circ}$ seeds sown 47 germinated. The first leaf of all of these seedlings was pale cream with a faint greenish tinge and all except 2 died within 3 weeks of germination. The two survivors lingered for another 4 weeks and produced minute pale yellow second leaves. At this stage they were destroyed by a hailstorm, but it seemed unlikely that they would have survived much longer.

$\mathrm{S}_{2}$ was also pollinated with green wattle $\mathrm{G}_{3}$ and again a comparatively good yield of seed was produced. Out of 50 seeds sown 33 germinated and of these 6 died without producing a leaf other than the cotyledons. The remainder showed a wide range of chlorosis. Some of these were difficult to classify because of rapid colour changes with ageing, but there appeared to be two main types, namely, YG which turned to $\mathrm{G}$ or light BG, and pale yellow-green (PYG) which gradually turned to YG. These two types were not clearly distinguishable and some confusion may have occurred in scoring.

A striking feature of this $F_{1}$ family was the high frequency of chimeras either variegated or having sectors of $B G$ and $Y G$ or PYG tissues. Out of 27 seedlings examined I I were chimeras, the numbers of normals, chlorotics, and chimeras being: BG 2, YG 2, PYG 12 ; chimeras BG and YG 4, BG and PYG 5, YG and PYG 2.

Many of the chlorotic seedlings were weak and 23 out of 27 died before it could be determined whether they were hybrid or not. Of those which remained one YG seedling was hybrid, while two BG and YG chimeras and one BG and PYG chimera were also hybrids. The occurrence and frequency of chlorotics and chimeras in this $F_{1}$ family was rather similar to that in backcrosses of the green $\times$ black hybrids to green wattle, a more detailed account of which is given below. 


\section{CHLOROSIS IN $F_{2}$ FAMILIES}

From the green and black wattle $F_{1}$ hybrids a total of $10 F_{2}$ families were grown, 6 of these being from hybrids in which green wattle was the seed parent and the rest, from $\mathrm{H}_{1} / 6_{3}-6 / 6_{3}$, the reciprocal cross. The segregation in these families is shown in table 2.

Differences in the degree of chlorosis between $F_{1}$ hybrid seedlings in the green-black hybrids was not very great and all chlorotics were classified as YG. In the $F_{2}$ families a very much wider range of chlorosis was encountered irrespective of the direction of the initial cross and there was apparently a relationship between the degree of chlorosis in the $F_{1}$ hybrid and its $F_{2}$. The $F_{1}$ hybrid $G_{33-24}$ was recorded as having a normal first seedling leaf and the $F_{2}$ from this hybrid segregated into $B G$ and $G$ seedlings only, in a ratio which agreed fairly closely with a $3: 1\left(x_{(1)}^{2}=3 \cdot 634\right)$. No truly chlorotic types appeared. In the $F_{2}$ families from $Y G G_{35}$ hybrids there was a wide range of chlororsis and for the purpose of record six seedling classes were made: BG, G, YG, and PYG mentioned above and, in addition, very pale yellow green (VPYG) and albino (A).

These classes were not clear cut and, as the leaf colour changed with age, scoring was difficult. Normal leaves show a considerable range in the intensity of the blueness, possibly due to variations in anthocyanin content, but green seedlings were clearly distinguishable from the normal. At first YG seedlings were quite distinct from BG or $\mathrm{G}$, but as the seedlings grew older the green colour became more predominant until eventually these seedlings were barely distinguishable from $G$ or the lighter shades of BG. PYG seedlings also became greener with age, eventually coming close to YG or G. The first seedling leaf of the VPYG seedlings was almost white, but the cotyledons, although somewhat paler than normal, were green. The first leaf of VPYG seedlings usually changed colour only slightly with age and almost invariably withered from the pinnule tips. The second leaf, if it appeared at all, was very small and nearly white. The great majority of these seedlings died within 3 weeks of germination. True albinos (A) appeared in two families. These seedlings had pure white or pinkish (due to anthocyanin) first leaves and colourless cotyledons. All these seedlings died soon after germination without producing second leaves. In some of these $F_{2}$ families a proportion of chimeras occurred, but none was recorded in those where black wattle was the seed parent of the cross.

In the normal blue-green leaf the palisade, mesophyll and guard cells are tightly packed with chloroplasts with well-defined outlines, and sections were a vivid deep green. The plastids of VPYG seedlings, although numerous and quite well defined, were colourless and appeared smaller than normal chloroplasts. A few plastids which seemed to have a very pale green tinge were found more especially in the guard cells, but this could have been an artefact. In PYG 


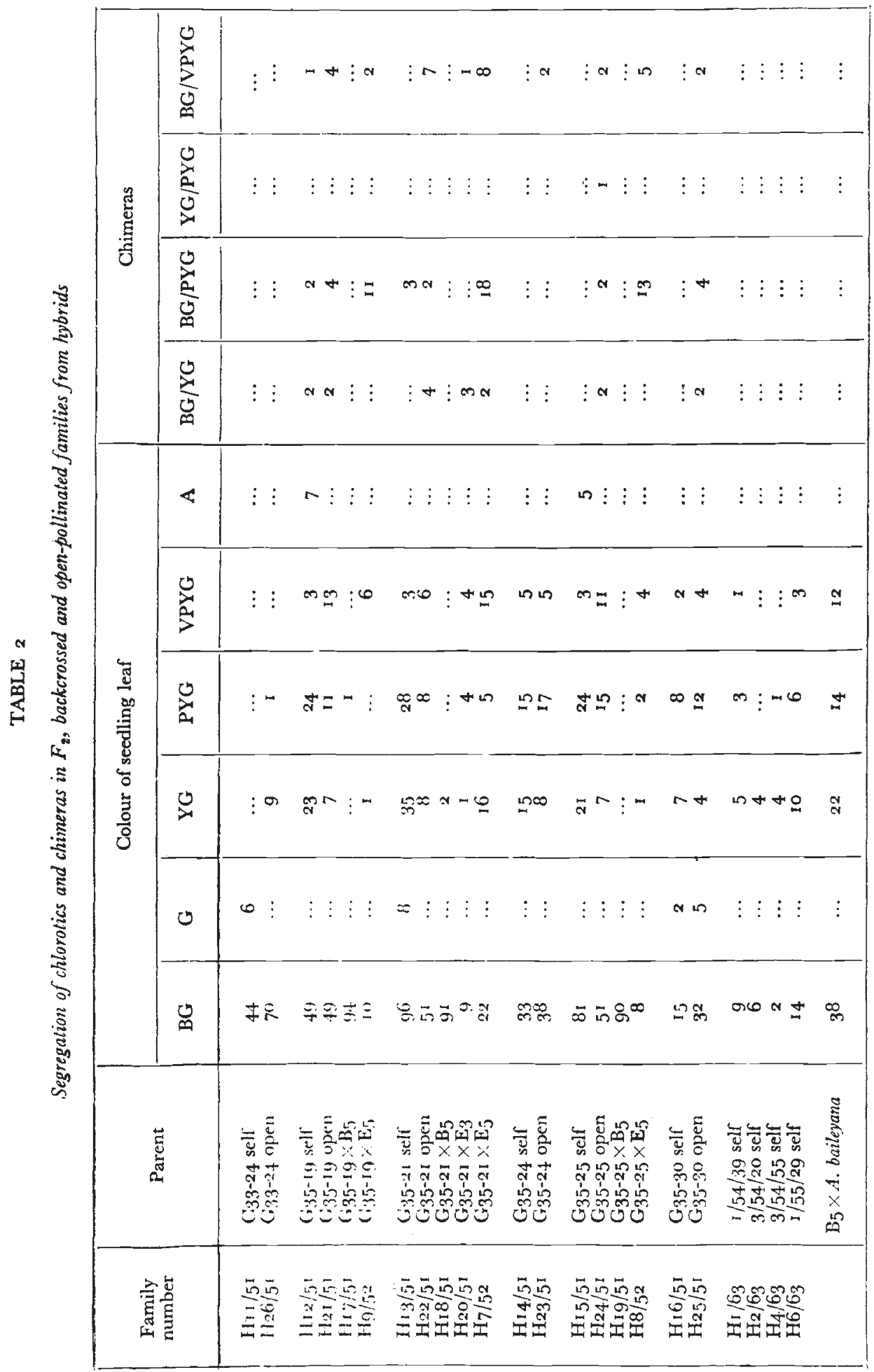


leaves, plastids had more colour than in VPYG, but they were yellowish rather than green. In the YG seedlings the chloroplasts were greener still and the outlines more clearly defined than in PYG or VPYG and they appeared to be larger and more numerous. Compared with normal, the chloroplasts of YG had a yellowish appearance, but not so markedly so as PYG seedlings. The degrees of chlorosis appear, therefore, to be due to a progressive diminution of chlorophyll content in the plastids accompanied possibly by a reduction in the size of the plastids.

As the trees grew older the foliage became normal green in appearance except for rapidly growing shoots, on which the young leaves were frequently yellowish to start with, but quickly became green.

Attempts to obtain $F_{2}$ families under controlled conditions from the $\mathrm{B}_{5} \times A$. baileyana and the green and black crossed silver wattle failed. The $\mathrm{B}_{5} \times$ baileyana hybrid set seed, however, by open-pollination and, from the position of the hybrid tree and its time of flowering, it was concluded that this seed must be the result of self-pollination. Segregation of chlorotics in this presumed $F_{2}$ family was very similar to that occurring in the $\mathrm{F}_{2}$ s from green-black hybrids, but no chimeras occurred (table 2).

\section{CHLOROSIS IN BACKCROSSED AND OPEN-POLLINATED FAMILIES}

When $\mathrm{G}_{35}$ hybrids were backrossed to both the green and black wattle parents the results were markedly different. $\mathrm{G}_{35}-\mathrm{I}_{9}, \mathrm{G}_{35-2 \mathrm{I}}$, and $\mathrm{G}_{35-25}$, used as seed parents, when backcrossed to the black wattle $\mathrm{B}_{5}$ all yielded a comparatively high number of pods per inflorescence and seeds per pod (table 2). The seedlings from these backcrosses were predominantly $\mathrm{BG}, 3$ chlorotics occurring in a total of 275 seedlings. These chlorotics may have been the result of selfpollination since the flowers were not emasculated before crossing.

When the samc three $F_{1}$ trees were backcrossed to green wattle, the hybrids again being used as seed parents, the set of pods was low and the backcrossed families segregated for a range of chlorotics similar to those occurring in the $\mathrm{F}_{\mathbf{2}}$ families, but a very much higher proportion of chimeras ( 37 per cent. of the total seedlings) occurred.

In the open-pollinated families the overall percentage of chlorotics did not differ greatly from the $\mathrm{F}_{2} \mathrm{~s}$, but there was a considerably higher proportion of chimeras in the former. The percentage of chimeras following open-pollination was intermediate between the $F_{2}$ families and the backcrosses to green wattle and, when the position of the hybrid trees in the plantation is taken into account, this may have some significance.

The $G_{35} F_{1}$ trees were growing in a small group at the edge of a green wattle plantation, but were fairly far removed from the nearest 
black wattle. The maximum flowering period of the hybrids largely coincided with that of green wattle and so was too early for all but a few black wattle trees. Seed from open-pollination could, therefore, result from selfing, intercrossing between the hybrids, or natural backcrossing to green wattle. The high proportion of chimeras in the controlled backcross to green wattle and the higher percentage on open-pollination, where some backcrossing to green was likely, compared with self-pollinated families suggest that the factors which cause the formation of chimeras have come from the green wattle side of the cross.

\section{THE CHIMERAS}

Both sectorial and periclinal chimeras occurred, the chlorotic areas appearing at different stages of development and showing various degrees of chlorosis. In some sectorial chimeras the first seedling leaf had chlorotic areas (plate, fig. I), but in many the first leaf appeared to be normal, while later leaves were partially or completely chlorotic (plate, figs. 2-3). Occasionally YG and A sectors occurred on the same plant, the A pinnules and pinnæ being almost invariably greatly reduced in size and, usually, they died back from the pinnule tips.

Two types of periclinal chimeras occurred. The commoner type had pinnules with green centres and white edges and the pinnules were somewhat reduced in size and of irregular outline compared with the normal (plate, fig. 4). In sections, no chloroplasts could be detected in the guard cells of the epidermis although they were clearly discernable in normal leaves. A considerable proportion of the spongy mesophyll contained chlorophyll, but there were numerous islands of colourless tissue. In these islands cell growth must, presumably, have been slower than normal, resulting in depressions on the leaf surface. The palisade layer, instead of forming a continuous band across the section, as in normal leaves, was broken-up by groups of colourless non-palisade cells and these, again, caused depressions and deformity of the leaf surface due to slower growth. Where present, the palisade cells contained numerous deep green chloroplasts which appeared to be normal in every respect. It would seem that in this type of periclinal chimera the layer from which the epidermis is derived contains no chloroplasts and that this layer has replaced the normal palisade tissue in some parts of the leaf. This is apparently a typical white over green chimera.

In the second type of periclinal chimera the young leaves tended to have white or pale yellow centres to the pinnules with flecks of green along the edges (plate, fig. 3 ) though some leaves were variegated green and white or yellow. Later leaves were pale yellow mottled with minute flecks of green, and the ends of some of the pinnules were definitely green.

A transverse section of a pinnule of a young leaf of one of these chimeras showed that there were chloroplasts in the guard cells and 
in the spongy mesophyll, but the palisade layer had no chlorophyll except for occasional very small islands of cells containing chlorophyll. In these cells the chloroplasts were paler than the normal deep green.

A section of a later leaf which was pale yellow mottled with green showed that the spongy mesophyll was filled with deep green chloroplasts, while the guard cells contained smaller but definitely green chloroplasts also. The palisade tissue consisted of groups of cells with deep green chloroplasts lying side by side with other cells completely lacking in chlorophyll. It was noted that the palisade cells containing chloroplasts always lay immediately above a leaf vein, and between the veins the cells contained no chlorophyll. It would seem, therefore, that there is some direct relationship between a vein and the presence of chlorophyll in the palisade tissue in this particular chimera. Otherwise this chimera was typical of the green over white type.

The chlorotic tissues usually persisted in the chimeras until the seedlings had formed some eight to ten leaves, but at this stage green tissue gradually became dominant. By the time the seedlings were some eighteen inches high the foliage was indistinguishable from normal.

\section{DISCUSSION}

Variegated, chlorotic, or albino seedlings caused by single gene changes occur comparatively frequently in inbred families of both green and black wattles (Philp and Sherry, 1946; Moffett, 1956), but the inbred families from the parents of the hybrids did not segregate for any of the genes causing chlorophyll deficiencies. Chlorosis in the hybrids must, therefore, have arisen as a direct result of interspecific hybridisation. At first sight it seemed likely that a nuclearplastid interaction similar to that which gave rise to variegated chimeras in Enothera (Darlington, 1949) was responsible for the chlorosis but certain differences in behaviour threw some doubt on this explanation.

The $F_{1}$ hybrids from which $F_{2}$ and backcrossed families were produced were made using green wattle as the seed parent. The hybrids had, therefore, green wattle cytoplasm and it could be expected, on analogy with certain results in CEnothera, that black wattle plastids, if they came over in the pollen, would be inhibited, but maternal plastids would not be. However, when the $F_{1}$ hybrid was used as female parent little chlorosis occurred in the backcross to black wattle, although further black genes, and possibly plastids, were being introduced into the green cytoplasm. On the other hand, there was a high degree of chlorosis in the progeny when green wattle was the backcross parent, although green wattle genes and again, possibly plastids, were being introduced into green wattle cytoplasm. It would seem, therefore, that factors other than the inhibition of foreign plastids in the maternal cytoplasm are involved. 
Behaviour very similar to that occurring in interspecific hybrids of Acacia has been reported in sweet clover (Melilotus spp.), where a high proportion of the interspecific crosses gave chlorophyll deficient hybrids (Bringhurst, 1951; Smith, 1954). In this genus the degree of chlorosis induced by interspecific hybridisation was, on the whole, more severe than that occurring in wattles. In the cross most extensively studied, $M$. alba $\times M$. dentata, $\mathrm{F}_{1}$ seedlings suffered from a lethal deficiency of chlorophyll and survived only when grafted on to normal sweet clover stocks. By this means Bringhurst was able to produce seedlings from backcrosses to $M$. alba and in these he found a range of chlorophyll deficiency from lethal types, similar to the $F_{1}$ hybrids, to normal greens. From the segregation in these families he concluded that the species differed by at least three genes which cumulatively conditioned chlorophyll reduction in heterozygous and homozygous combinations.

While such a scheme may apply to wattle alsi), on the meagre data, it has not been possible to fit the results into any clear genetical pattern, possibly due to the difficulty in assigning the chlorotics to clear-cut classes. It would seem, however, that an explanation of the hybrid chlorosis might lie in the basically similar hypotheses put forward independently by Stern and Michaelis to account for the occurrence of plasmon sensitive genes in Epilobium (Caspari, 1948). They suggest that this phenomenon is most nearly related to position effects since in both phenomena the action of the gene is not autonomous, but is influenced by the intracellular environment. Stern proposes that there is competition between genes in different positions for larger or smaller amounts of a substrate which is available in limited quantities, while Michaelis suggests that similar genes from different species produce slightly different subtrates, some of which may combine to form an inactive compound. In both cases it must be assumed that every time a paternal gene is inhibited a maternal one would be also. This would seem to occur in Acacia.

In Epilobium the plasmon sensitive genes did not cause plastid effects, but a similar hypothesis, if applied to hybrid chlorosis in wattle, would explain many of the facts. If it were assumed that similar green and black wattle genes in somewhat different positions on the chromosomes competed for a substrate, initially in limited supply, but necessary for the formation of chlorophyll, then chlorosis would result. If the supply of the substrate increased as the seedling grew older then chlorophyll formation would be resumed. The seedlings would, however, be heterozygous for such position effects, and segregation in the $\mathrm{F}_{2}$ might result in greater or lesser competition for, or inactivation of, the substrate with the result that a much wider range of chlorosis would occur, the most extreme cases being those in which chlorophyl formation was permanently inhibited. Some weight is lent to the argument that chlorosis is due to a lack of a substrate by the fact that islands of green tissue occurring in chlorotic 


\section{Plate}

Fig. I.-Chimera affecting the first and second seedling leaves. Chlorotic pinnules reduced in size, very pale yellow-green with green flecks on edges. Probably green-over-white chimera.

FIc. 2.-First leaf normal. Second leaf with one pinna pale yellow-green, other slightly variegated. Third leaf with one pinna variegated. No reduction in pinnule size in chlorotic areas.

Fig. 3.-First three leaves normal. Fourth leaf, one pinna variegated. Fifth leaf, almost completely pale yellow-green, but no reduction in pinnule size. Sixth leaf variegated, Probably green-over-white chimera.

Fig. 4.-Pale edges and green centres on all pinnules after first leaf. Pinnules narrow and somewhat irregular in shape owing to failure of chlorotic tissues to develop fully. Probably white-over-green chimera. 


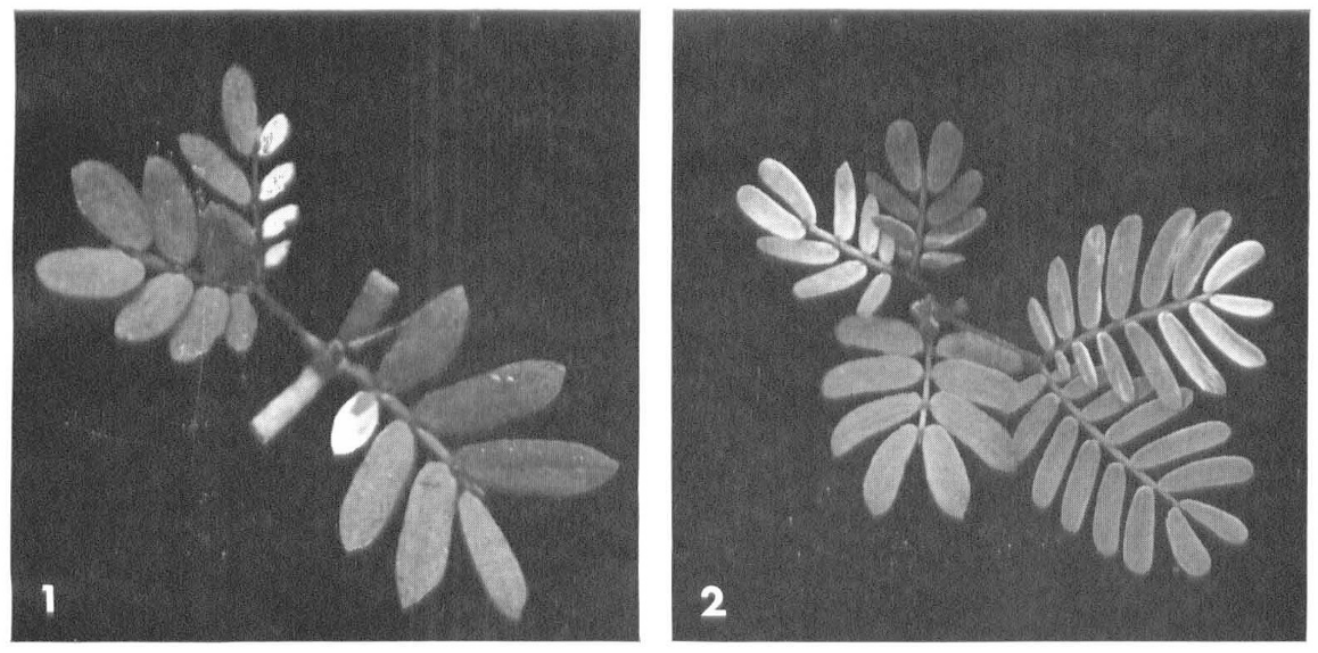

3
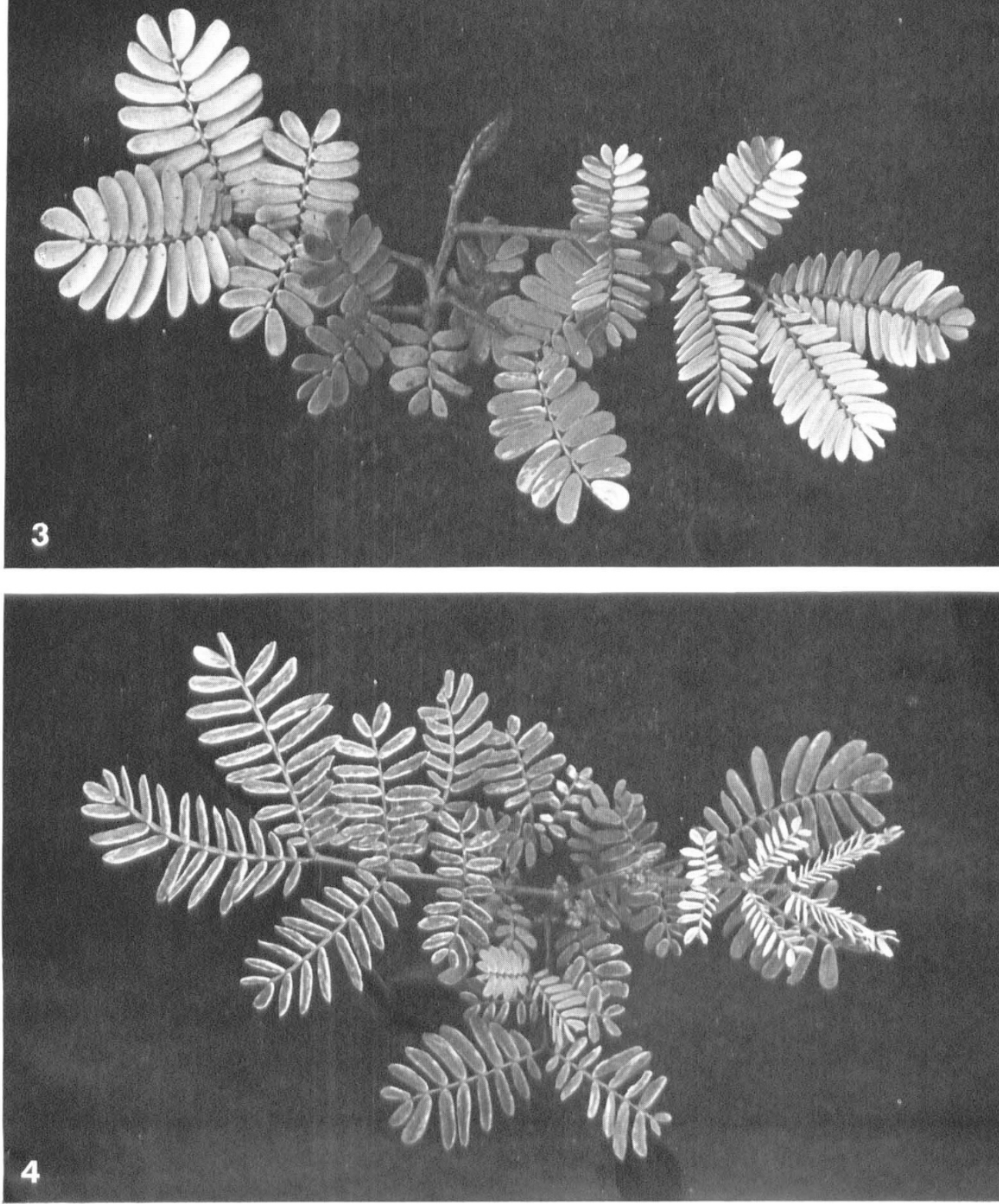
areas in chimeras were usually found in close proximity to a vein. This hypothesis would also explain the different behaviour on backcrossing the $F_{1}$ hybrids to the green and black parents. Caspari (loc. cit.) quotes cases in Epilobium where maternal genes can also become plasmon sensitive. When this occurs, backcrossing of the hybrid to the maternal species sometimes results in greater phenotypic variability, while on backcrossing to the paternal species, the inhibitions tend to disappear.

Even if this explanation of chlorosis is acceptable it does not account for the chimeras. The types of chimera in wattle are very similar to those in Pelargonium recently classified by Tilney-Bassett (I964), but it would seem that in wattle the mode of origin may be somewhat different. Plastid differential chimeras may arise either by spontaneous plastid mutation or by sorting out of two kinds of plastids from a mixed cell or zygote. Chimeras in Pelargonium are generally thought to arise in the second way. In the wattle, on the other hand, hybrid chlorosis seems to affect all the plastids in a cell, not those from one parent only, and it is doubtful if there are, in fact, two types of plastids which could "sort out" into different tissues. Evidence that this is so is given by the fact that leaves of many of the chlorotic seedlings recover their ability to form chlorophyll without further cell divisions, while in others there is a degree of chlorosis without the tissues separating into well-defined chimeras. Also, as mentioned above, in some chimeras, islands of green tissue occur which are usually associated with the veins, whereas if these islands were due to " sorting out" they would be expected to occur at random over the leaf surface. It would seem, therefore, that in the formation of chimeras, in certain meristem layers the gene cytoplasmic relationship must be altered in some way, possibly by mutation or even somatic chromosome rearrangement, so that in some tissues normal chlorophyll formation is permitted, while in others it is temporarily or permanently inhibited. There is some evidence that the factor which causes cell instability and the consequent formation of chimeras is introduced from green wattle and that the instability increases with increasing green wattle gene dosage. It is possible that green wattle carries a gene which gives rise to a degrce of somatic instability.

\section{SUMMARY}

I. Hybrids from crosses between certain species of tan wattles usually had a chlorotic first seedling leaf. The degree of chlorosis varied within $F_{1}$ families and also with the individuals and species involved in the cross.

2. The $F_{2}$ from hybrids between green and black wattles segregated into blue-greens and a range of chlorotics, from lethal albinos and very pale yellow-greens to viable yellow-greens many of which eventually recovered normal colour. A few chimeras occurred in the $F_{2}$ families. 
The $\mathrm{F}_{2}$ from $A$. baileyana $\times$ black wattle segregated into a similar range of chlorotics but no chimeras occurred.

3. The green $\times$ black hybrid was comparatively fertile on backcrossing to black wattle and very few chlorotics appeared in the progeny. The same hybrids were fairly sterile when backcrossed to green wattle and there was a high proportion of both chlorotics and chimeras in the progeny.

4. The chimeras were both sectorial and periclinal and appeared to be typical of the types described in Pelargonium and other plants. There was an indication that chimeras were caused by some factor brought in by green wattle and that the proportion of chimeras increased with increased green wattle gene dosage.

5. The origin of chlorosis and chimeras is discussed.

\section{REFERENCES}

BRINGHURST, R. S. I95I. Genetic analysis of chlorophyll deficiency in Melilotus alba $\times M$. dentata hybrids with some observations on meiotic irregularities. Genetics, 36, 543 .

CASPARI, E. 1948. Cytoplasmic inheritance. Advances in Genetics, 2, 1-66.

DARLIngton, C. D. I949. Genetic particles. Endeavour, 8, 5I-6I.

MOFFETT, A. A. 1956. Genetical studies in Acacias. I. The estimation of natural crossing in black wattles. Heredity, 10, 57-67.

MOFFetT, A. A., AND NIXON, KATHLEEN. 1958. Genetical studies in Acacias. II. Leaf characters in hybrids between green and black wattles. Heredity, 12, I99-2I 2.

PHILP, J., AND SHERRY, S. P. I946. The degree of natural crossing in green wattle Acacia decurrens Willd, and its bearing on wattle breeding. J. S. Afr. For. Ass., 14, I-28.

PHILP, J., AND SHERRY, S. P. I949. The genetics of hybrids between green wattle (Acacia decurrens) and black wattle (Acacia mollissima). 7. S. Afr. For. Ass., 17, $1-53$.

sMrth, william K. I954. Viability of interspecific hybrids in Melilotus. Genetics, 39, 266-279.

TILNEY-BASSETT, R. A. E. 1963. The structure of periclinal chimeras. Heredity, $18,265-285$. 